\title{
レビィー
}

\section{XXVIII. 煙霧体}

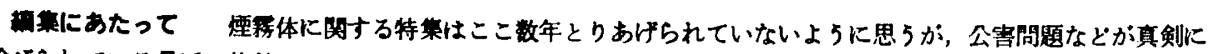

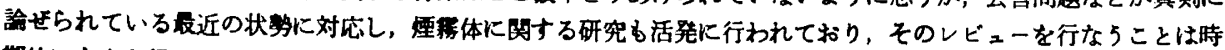

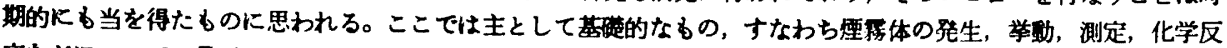

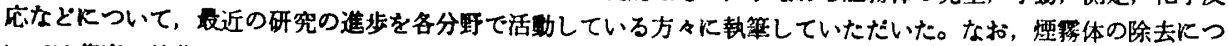

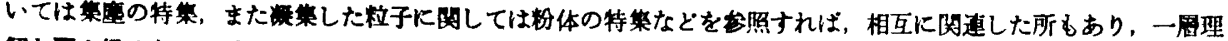
解を栗め得るるのと思かれる。

（苗 高息洋一*.三神 尚*)

\section{XXVIII-1. 洷 体 の 発 生**}

1. は し かi き

大気污染で問題にされている大気中に浮遊する粒子状 物質をはじめとし，局所的には火災で発生する䃌，労㑬 環境内に発生して職莱病をひきおこす有害粉しんなど, 煙蝚体（Aerosol）についての成心の度はますます強く なっている。

そこで, Aerosol の性質を調くるに当って，また Aerosol 測定器の性能，あるいは集じん装展の捕集効率など を調へるに当って必要となる僄準 Aerosol を人工的に発 生させる方法について述くる。

Aerosol の発生法を分類してみると次の三通りに大別 することができる。

(i) 分散機窠炕上る方法

(ii) 化学反统泎上る方法

(iii) 凝摍機檴灴上万方法

ところで, 蒸気の㩯縮機構による Aerosol の発生につい ては，木谷らのレビュー26)があるので，本稿ておいては (i) の分散機構による発生法に重点をおく。

\footnotetext{
- 東京工来大学示子所工学研究所

**昭和 43 年 10 月 2 日受理

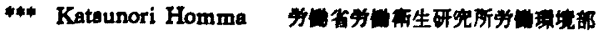

\section{2. 分散機潇による Aerosol の発生法}

\section{$2 \cdot 1$ 物体の分数による方法}

粉体を乾燥状態のままで気中に散布して Aerosol とす る方法には，単純に流動している空気中へ粉体を落下さ せるとか、フラスコ中に粉体を入れておき，そこへ加圧 空気を送って粉体粒子をフラスコ内に舞上げると同㭙に 外へ送り出す方法, 粉体詝蔵器より一定量つつ供給した のを分散させながら分級によって粒度を均一にして系外 へ放出する仕租みを備えたるのまで，この種の発生装置 (Dust feeder, Powder dispenser, Powder disseminator などと呼ばれる)は極めて多種多様である。

ところで，労働術生の分野で颣じんの有害性を調くる のに動物へ数じんを夢入させて行な5 方法が 1940 年代 にさかんと進められた。その実験には，微細粉じんを発 生し吸入装異へ供給することが必要となり，粉体の分散 による Aerosol の発生装滑が次々汇考案され，この時代 に一応の形䖩がまとまったと云える。

即ち初期住はU.S. Bureau of Mines ${ }^{51)}$ で開発された Ejector 方式をるとKし，粉体の供給に振動式すべり 台(3)中回枟板(5)を組合せて，ホッバに蓄えられた㸮体を 间断なく流動空文中へ送り出す方式とか，極めて低涨度 


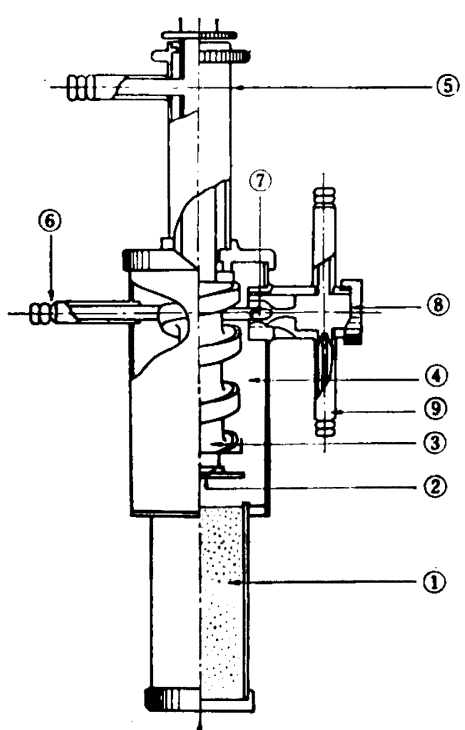

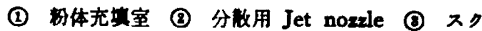

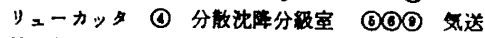
管 (7) Ejector (2) Baffle plate

因 1 興式 Dust feeder の主要部 （内部模造図）
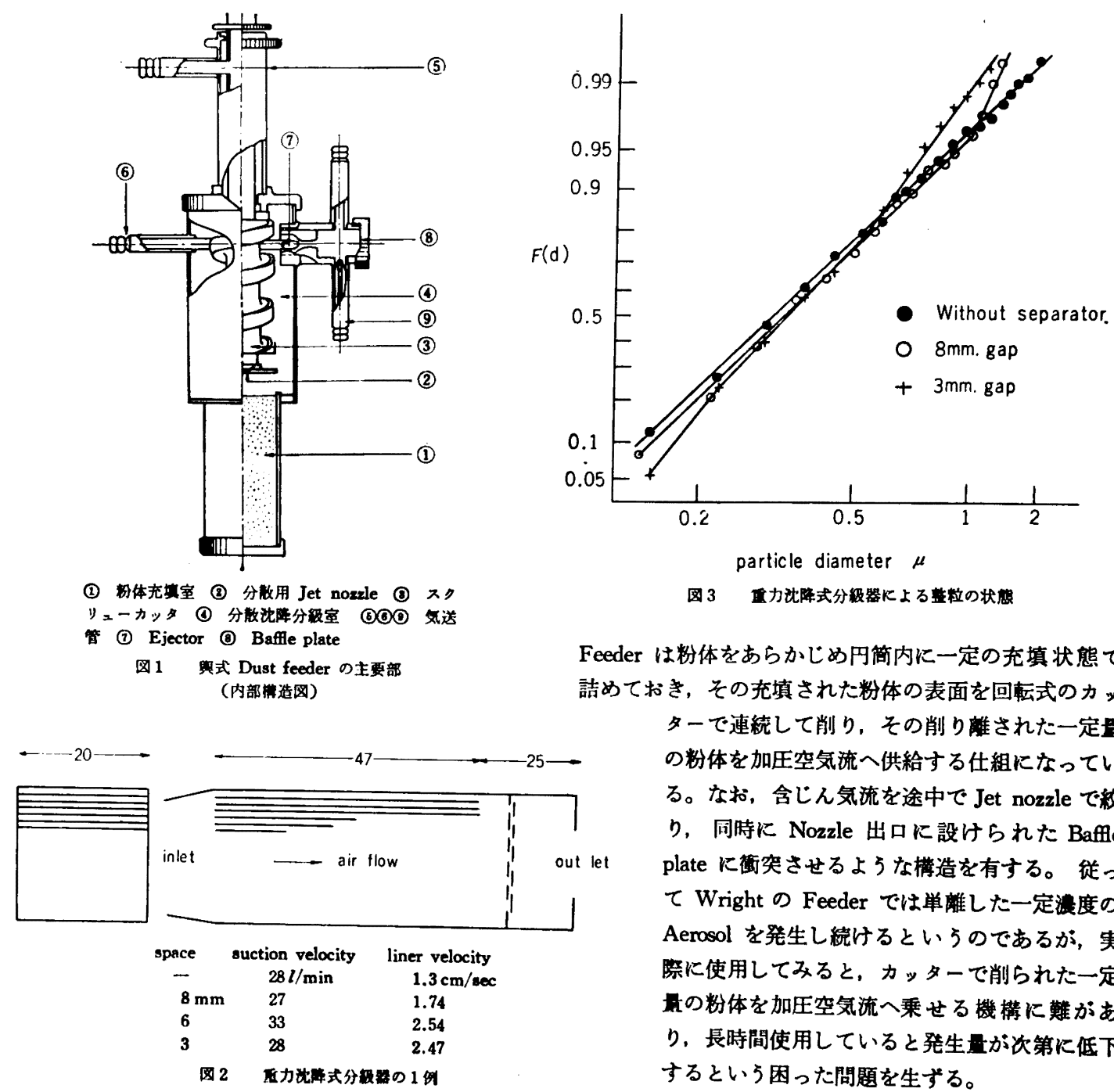

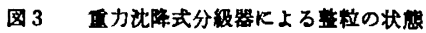

Feeder は粉体をあらかじめ円簡内に一定の充填状態で 詰めておき，その充填された粉体の表面を回転式のカ , ターで連続して削り，その削り離された一定量 の粉体を加圧空気流へ供給する代組になってい る。なお，含しん気流を途中で Jet nozzle で絞 り, 同時に Nozzle 出口に設けられた Baffe plate に衙突させるような構造を有する。従っ て Wright の Feeder では単離した一定港度の Aerosol を発生し続けるといらのであるが，実 際に使用してみると，カッターで削られた一定 是の粉体を加圧空気流へ乗せる機粠に難があ り、長時間使用していると発生量が次第に低下 するといら困った問題を生ずる。

この久陥を解決するために考案されたのが興

で有害作用を示す粉じんを小動物に吸入させて調べる は，少贵の粉体を連梡して供給する機構を備えた発生装 圈 ${ }^{3,53)}$ ，更に Ejectorでの負圧のみを利用して吸引散布 したのでは吸入実呀上で不必要な $10 \mu$ 以上の大きな粒 子まです供給することになるので，前るって分級するた めの装渲が組込れたるのへと発展した。分級方法として は，篩を用いる方法5,43)，重力沈降を利用する方法32)， またその両者の組合わせ522などがとられた。

ところで粉じんの供給においては，任意に選定した一 定の Aerosol 暴度を長時間にわたって保たねばならない 場合が多い。その采件に合せて粉体より Aerosol を発生 させるには単純な Ejector 方式のみでは困難なところか

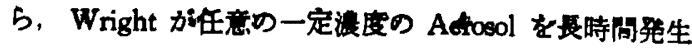
させることのできる新しい形の装剭(4)を作った。この によって作られた Dust feederである。図1はその主要 部の構造を表したすのである。この発生方法は円簡(に 均一な圧力で充填された粉体をスクリニーカッタ(8で一 定量つつ削ると同時に分散 Nozzle (2)からの Jet 気流で 時に Baffle plate (Bに衙突され，そこで $90^{\circ}$ 方向からの 加圧空気流○に乗せられ系外へ放出される。

前述の発生装睓によれば，ほぼ一定䈨度の Aerosol を 発生させることはできるが，一般に強く㠜集している粉 体を戦離した Aerool として発生させることは容易て い。そればかりか， Ejector や Baffle plate との作用によ

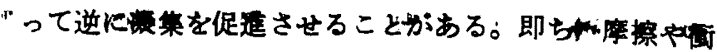
笑作用で静電気を生し，これが粒子に带䉓して，粒子同 粉体を分散室(に舞上げる。分散室内で重力沈降により 分級された維細粒子は Ejector (7)により吸引されると同 


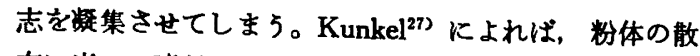
布に当って瑱射 Nozzle，送気管，あるいは Baffle plate などと粉体との間での相互作用により発生する静電気 は、それぞれの物質によって大きな差が認められること を報告している。一般に装置の材料が奄気抵抗の大きな 物質で作られている場合，および粉体との間の帯電列で 大きな電位差をすつ物質で作られている場合などで，そ の効果が大きい。従って, Feeder によって粒度分布の小 さなAerosol を得るには慣性効果 ${ }^{53)}$ とか重力沈降を利用 した分級操作による必要があると云われている。そこで 325 mesh 以下に節った石英粉体を興式 Dust feeder Kて 散布し、発生した Aerosol を图 2 に示すような重力沈降 式整粒器を通過させた場合の粒度分布を調へてみると図 3のことくで，分級操作を加えても粒度分布を大きく変 ることは困難である。

このように分敕方式では維細な離した Aerosol を作 ることが困難なところから，Druett”訳は塊状または 粒状の物質を回枟する Drum 内で互いの接触によって破 砩させ, その破硉によって Drum 空間に舞上った敏細粒 子を空気によって運び出す方式の Aerosol 発生装置を作 ったここの装置から発生された Aerosol は大部分が $1 \mu$ 以下の単誰した粒子で，その粒度分布の小さいことを報 ビている。

また，あらかじめ粉体粒子を単分散粒径までに分級し

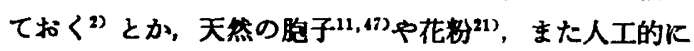
作られたガラスビース，ポリ㙁化ビ二ル粉末199，カーボ ンブラック（例えば三池井20，白石ガストン）など, 極めてよくそろった粒子からなる粉体を Dust feeder 散布すれば，単分散に近いAerool を得ることができる。

なお，同質のるので焦意の粒径の Aerosol をとなると， 粉体分散法では不可能で，他の発生法によらなければな らない。

\section{$2 \cdot 2$ 洨体の分枚による方法}

加王気体によって液体を分散し Aerosol を哭生させる 方法についての研究は，液体然料の然焼に関する基礎的 研究として，拔山などの系統たった一連の報告(1)があ る。それによれば，加圧空気によって噴籍されて生成す る液滴の平均粒径 $\bar{d}$ は，噴籍される液量 $\left(Q_{L}\right)$ 飞対す る加压空気量 $\left(Q_{G}\right)$ との比, および噴射 Nozzle を通過 する液体の流速 $\left(v_{L}\right)$ と空気の流速 $\left(v_{a}\right)$ との間の相対 速度 $\left(v: v_{a}-v_{L}\right)$ とによって定まり, Nozzle の形状や 大きさによって左右されないことを見出し，平均粒径は （1）式より算出できるとした。

$$
\bar{d}=585 \frac{\sqrt{\sigma}}{v \sqrt{\rho}}+597\left(\frac{\mu}{\sqrt{\sigma \rho}}\right)^{0.45} \cdot\left(1000 \frac{Q_{L}}{Q_{a}}\right)^{1.5}
$$

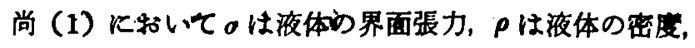
$\mu$ は液体の粘性係数である。更飞，その粒度分布は（2）

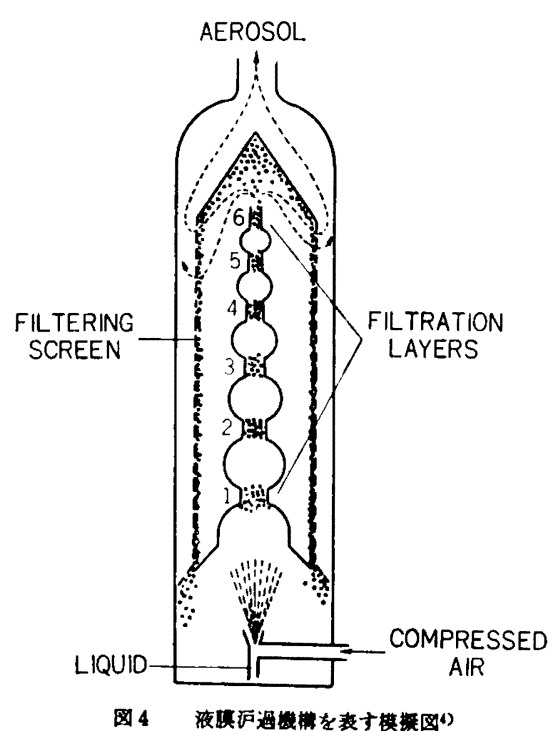

の実験式によって一般化することができた。

$$
\frac{d n}{d x}=a x^{p} \exp \left(-b x^{q}\right)
$$

(2) Kおいて，a，b，p，q1それぞれ実験的に求められ る常数で, $Q_{G} / Q_{L}>5000$ なら $p=2, q=1$ となる。

$a$ は $x=0$ での $\left(1 / x^{p}\right)(d n / d x)$ の值で，計測した粒 子数 $(n)$ が变れば变る值であって粒度分布に直接関㐿 がない。従って問題はbにあり,これは液体の密度, 表 面張力それに相対速度によって左右される。尚, 実験結 果では水、アルコール, クリセリンなどのいずれからす 多分散状態の Mist を生成した。また本間は市眅の医療 用 Nebulizer にて不撣発性の油から Mist を発生し, 光散 乱を利用した粒度分布測定器 (例えば ROYCO Particle counter) にて粒径を測定し，偏位俰数 $(\alpha)$ を求めてみ

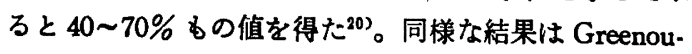
$\mathbf{g h}^{15)}$ の Wax の分散からも得られている。

そこで, 液体の分散から単分散の Mist を発生させる には、ただ単純に Jet 気流にて吹き干切るだけでは不可 能で，次にあげるような方法に従わねばならない。

(i ） 発生した Mist を分級によって整粒する方法

（ii）液体を Capillary より少量つつ一定典を供給しながら 分散させる方法

(iii）高速で回転する円板の中心部に液体を少量つつ一定量 を注き，遠心力を利用して分散させる方法。

第 1 番目の方法を用いた発生装置としては，Dautrebande の Atomizer D-304), Lauterbach の Nebulizer ${ }^{30)} な と ゙$ がある。これらの分級方式は図 4 亿示すような液膜によ

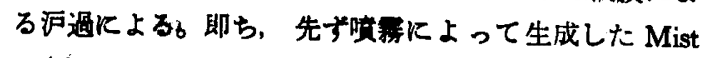
のFitering screen に捕集されると夜脫となって Scroen が目を覆う。ところが、沃の Screenを通過しなければ 


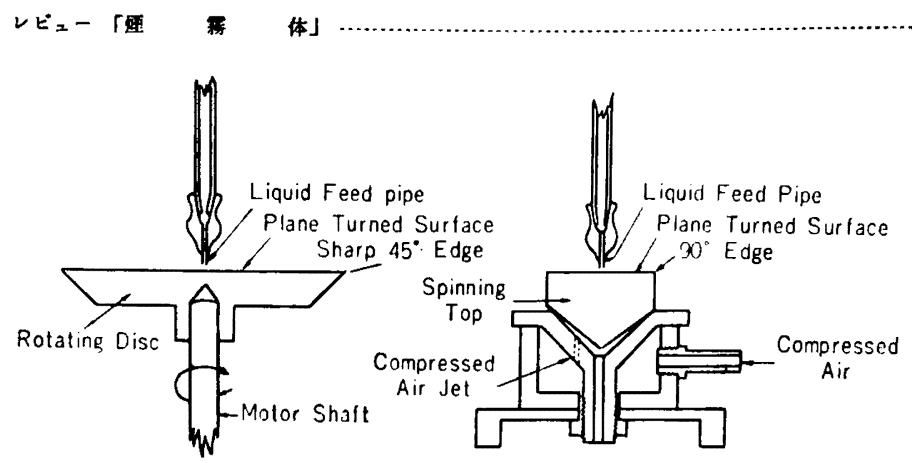

a) Spinning desk aprayer $\quad$ b) Spinning top sprayer 图 5 回云円板式 Aerosol generator ${ }^{60}$ )
2.67）を得ている。

この発生装眐によると、極めてよく そろった主粒子と，それに付随する副 粒子 (Satellite と呼ばえれる) とが発 生する。

主粒子の粒度分布については May が水と D.B.P. とについて発生した Mist を, 酸化マグネシューム粉末で襍 われたガラス板上に捕勧し，光学顕微 鏡で観察して求めた結果があるが,

D.B.P, では $\alpha=0.014$, 水では $\alpha=$ 0.031 を得ている。副粒子は Rotor K 空気は外に出られないところから，液膜を破って通過す ることになる。その際，液膜は自己の粘性，界面張力 と，空気の流速などにもとすいて平衡状態での孔径をる つ59。そこで，この液膜孔が分級作用を行ない，粘度分 布の小さな Aerosol を発生させる。

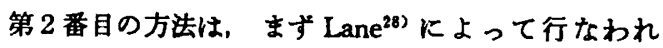
た。Lane は細い Capillary（内经 $0.45 \mathrm{~mm}$ 注射針）より 液体を少量つつ滴下させるととすに, 空気をCapillary の 側面より強く吹いてゃり，均一な Mist を発生させた。 なお Mist の粒径は液体の沈出量と空気の流速とによっ て定まり，粒径の大きな Mist 程粒度分布は小さくなり 均一な Aerosol を発生する。

この発生法で Capillary を機械的に振動16,34,35, (9)させ ると，更によくそろった Mist を能率よく発生させるこ とができることを Dimmock ${ }^{6)}$ が認めた。

しかし Capillary 法はAerosol として気中に安定な状態 で浮遊するような微細な Mist を発生させることが出来 ない点で，利用篹围が極めて狭い。

第 3 番目の方法を用いた発生装目は，近年特に注目を 浴び，単分散 Aerosol を必要とする分野で使用されてい $3^{37,61)}$ 。原法はWalton と Prewett ${ }^{60)}$ とよって稆介され た Spinning desk sprayer および Spinning top sprayer の

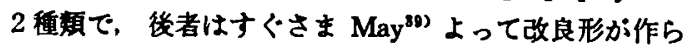
れた。2つの Sprayer の相遠は前者が Motor drive 式, 後者が Air drive 式である。この発生法の仕組みは, 回 転している Rotor の中心部に液体を注ぐと，その液体は 虺心力を受けて, rotorの維より均一な Mist となって瓜 散するのである。発生する Mist の粒径 (d) は Rotor の 径 (D), Rotor の回枟速度 $(\omega)$, それに液体の密度 $(\rho)$

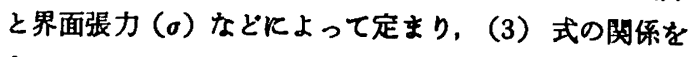
ชつ

$$
d \omega(D \rho / \sigma)^{1 / 2}=C
$$

但し, Motor drive 式の低速回伝の場合と Air drive 式 の高速回転の场合とで若千の差が视められる。奜臥結果 からCの平均值として $3.8^{60}$ ) (樶大值： 6.55 , 最小值:
供給される流量が多くなる程多量に発生するととすに粒 径す大きくなるので，単分散 Mist を得るには液量を 1 $\mathrm{ml} / \mathrm{min}$ 以下にする必要がある。

ところで，この回転円板法では回転数が高い程微細な Aerosol を発生させるところから, 初期にはるっぱら Air drive 方式 (Air motor ${ }^{62)}$ 式とす呼占) が用いられたが, この加圧空気を Rotor に吹きつけて高速回転”させると, 因 5-bからわかるよ5に Rotor が固定されていないた め, 回枟が不安定になることがあり，長時間使用では一 定状態（粒径，港度とす）の Aerosol を発生絩けること ができない。そこで，Motor drive 方式での高速回転化 の問題が生じ, Ryley ${ }^{48)}$ が D. C. motor/Inductor alternatorの組合せで発生した高周波を特種な Induction motor に供給し，90000 rpm もの回転を円板に与えることに成 功し解决を見た。

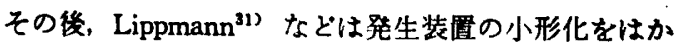
るために, Synchronous motor を採用し、AC 1000 cycle を供給ナることによって $60000 \mathrm{rpm}$ を出せる小形の発 生装眉を完成した。

尚，近年 May は更に Air drive 方式の改良を重ね(0)， Rotor を半固定することにより，超高速回転で長時間使用 してる一定の Aerosol を発生し続ける発生装目を作り,

Air-drive 法の持ち味を，一段と発腪させた。

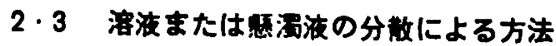

この発生法は，2.2 の方法に液体の蒸発操作を加え ることにより, 主として固体の Aerosol を発生させる场 合に用いられている。

溶液から Aerosol が作られた场合，その粒径は (4) 式 で

$$
D_{p}=D_{0}\left(\begin{array}{c}
V_{p} \\
V_{0}
\end{array}\right)^{1 / 8}
$$

で表わされることく, 主として溶筫の莨度と Mist の粒 径 $\left(D_{0}\right)$ に侬存し, 粒度分布は Mist の分布がそのまま 継承される。従って策分散の Submicron aerosol を発生 させるためには，前記単分散 Mist 発生法によるととも 

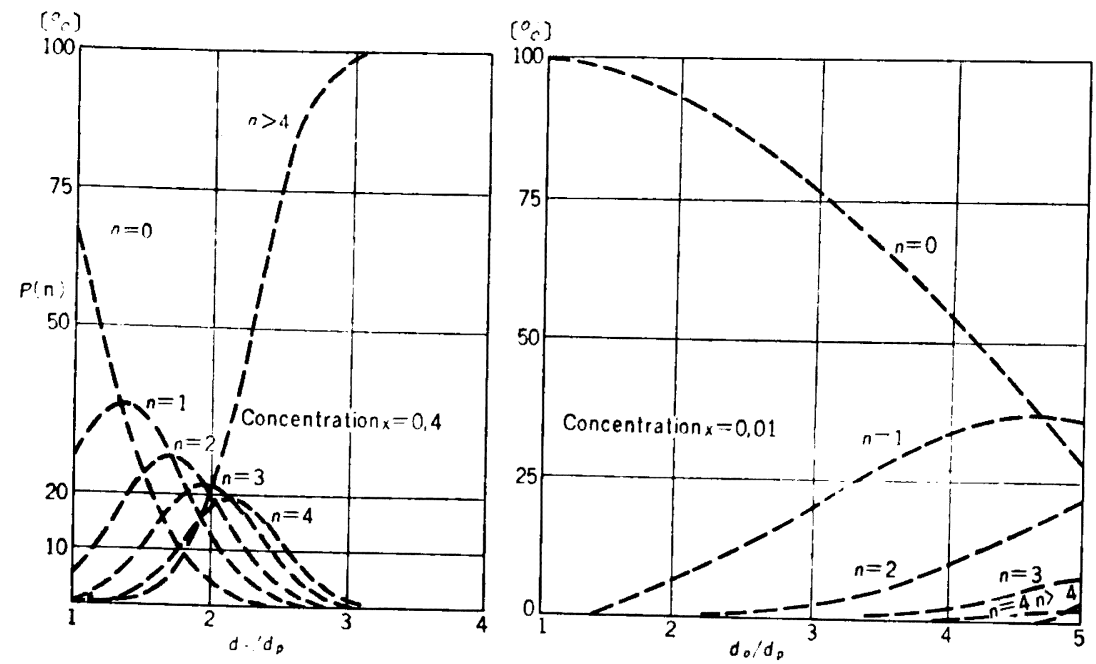

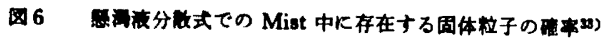

に，溶質浱度を低くしなければならないことは当然であ る。一段によく用いられる客筫としては $\mathrm{NaCl}^{17,38,44,56 ， ~}$ 59)を代表とする矰頼 ${ }^{30)}$, Methylene blue を代表とする染 料10,50,62)などがある。

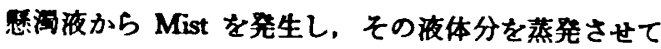
固体の単分散 Aerosol とする方法は, Dow Chemical Co. の Polystyrene latex の出現によって煩繁に行なわれるよ 5Кなった29,33,46,50)。

その他, 均一な Hydrosol をあらかじめ作っで,23,55), これを分散させる方法，また先に記した均一粒径をるっ た粉体粒子を液体中に琹眮させた後で分散させる方法な どをとれは，単分数 Aerool を発生させることはできる。

しかしそれには、, Hydroeol の状管で完全に単離してい ることが必要条件であり，また散布された各々の Mist の中には1ケの固体粒子しか存在することがゆるされな い。その场合，1 1 ケの Mist の中K固体粒子が存在する 確率恃 Poisson 分布飞従了ところから，次のように表わ される。

$$
p(n)=\frac{(\bar{n})^{n}}{n !} \exp (-\bar{n})
$$

ところで

$$
\bar{n}=x\left(\frac{d_{0}}{d_{p}}\right)^{2}
$$

なる関係がある。

そこで，忽汿液中の固体粒子浪度（x）が $40 \%$ と $1 \%$ との堵合について, Mist 中に存在する固体粒子の確率を 計算してみると因 $6^{33) の よ 5 K な る 。 ~}$

従って, 単離した固体の Aerosol を得るためには, Mist

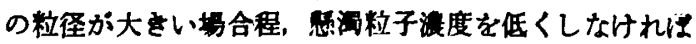
ならないことが明らかである。
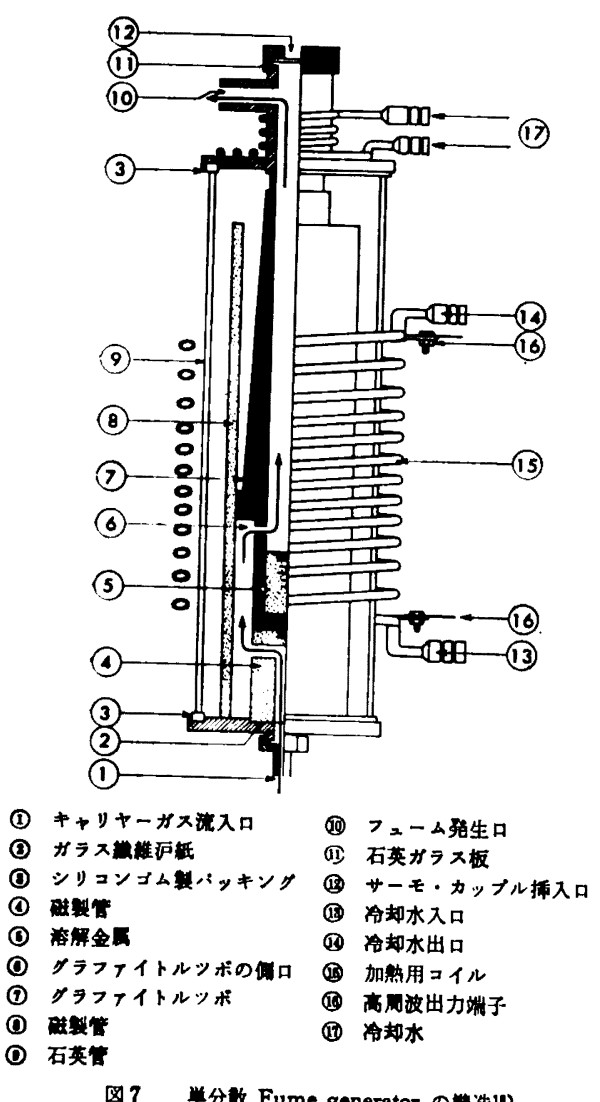

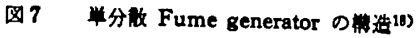

また発生した Mist は直ちに液体が蕟発されるように

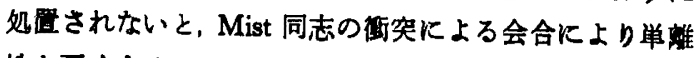
性を覀くする。 


\section{3. 化学反応による Aerosol の発生}

Fuchs $^{13)}$ などが述べているよ5に，化学反応を利用し て単分散の Aerosol を発生する方法は少ない。

その中で, $\mathrm{NH}_{3}$ と $\mathrm{HCl}$ との反応による $\mathrm{NH}_{4} \mathrm{Cl}$ aerosol の生成、また $\mathrm{SO}_{3}$ と $\mathrm{H}_{2} \mathrm{O}$ とから $\mathrm{H}_{2} \mathrm{SO}_{4}$ aerosol の発生 などは，古くからよく知られてはいるが，ただ単に両者 さ反応槽内で混合しただけでは多分散の Aerosol しか得 られない。ところで, Fuchs と Oschman ${ }^{12)}$ が $\mathrm{H}_{2} \mathrm{SO}_{4}$ aerosol を発生させるに用いた Jet-gas 混合法によれば単 分散のるのを作ることができる。

また化学反応を柴外線照射下において行わせて Aerosol を生成させる方法に, Carbonyl iron の葵気より $\mathrm{Fe}_{2} \mathrm{O}_{3}$ の Aerosol の発生 ${ }^{22)}$, Methylacrylate monomer より Polymer particle の生成などがある。これらの反応では，蒸 気の䇠度と紫外線が照射されている反応管内を通過する 速度が主成する Aerosol の粒径を支配する。

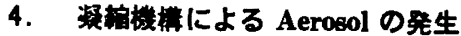

Sinclair-LaMer 法は単分散の Submicron aerosol を発 生させるための有効な方法として, 現状においても極め て広く使用されている24,37,57,58)。

文

1) Beams, J. W.: J. Appl. Phys, B, 795 (1937)

2) Boetjer, A.M. and Vintinner, F. J.: J. Ind. Hyg. Tox, 28 , 101 (1944)

3) Church, F. W. and Ingram, F.R.: J. Ind. Hyg. Tox, 30 , 246 (1948)

4) Dautrebande, L.: "Microaeroeol" (1962) Academic Press. New York.

5) Deichman, W. B.: J. Ind. Hyg. Tox., 26, 334 (1944)

6) Dimmock, N.A.: Nature, 186, 686 (1950)

7) Druett, H. A. and Sowerby, J.M. : Brit. J. Ind. Med., 3, 187 (1946)

8) Edwards, G.R., Evans, L.F. and LaMer, V.K. : J. Colloid Sci, 17, 749 (1962)

9) Espenscheid, W.F., Matijevic, E. and Kerker, M. : J. Phys. Chem., 68, 2831 (1964)

10) Flesch, J.P., Norris, C. H. and Nugent, A. E. : Amer. Ind. Hyg. Assoc. J., 28, 507 (1967)

11) Friedlander, S. K. and Johonstone, H.F.: Ind. Eng. Chem., 48. 1151 (1957)

12) Fuchs, N.A. and Oschman, N.: Acta Phys.-chim. U.S.S. $R ., 3,61$ (1935)

13) Fuchs, N.A. and Sutugin, A.G.: "Aerosol Science" (edited by Davies, C.N.) (1966) Academic Press. London and New York.

14) Gteen, H.L. and Lane, W.R.: "Particulate Clouds: Dusts, Spokes and Mists" (1964) Spon Ltd. London.

15) Greenough, G.K.: J. Sci. Instrum., 37, 123 (1960)

16) Harris, W. J.: J. Sci. Instrum., 41, 636 (1934)

17) Homma, K. Koohi, S. and Salobe, H. : Bull.Nat. Inat Ind. Health, No. 2, 57 (1959)

18) Homms, K. : Ind. Health, 129 (1966)
ところで㠜縮機棈を用いて $\mathrm{NaCl}$ ょり単分散の Aerosol を発生させる場合の問題点についてふれている二，三の 諭文を紹介する。Espenscheid などは一段加熱自己凝縮 法 ${ }^{36)}$ では， $\sigma_{\theta}=0.24(\bar{d}=0.54 \mu)$ と多分散 Aerosol しか 得られなかったので，LaMerなどの他核挿入，再加熱 方式にて行ったところ， $\left.\sigma_{0}=0.115^{9} （ \bar{d}=0.54 \mu\right)$ と均 一な球形粒子の発生を見た。つきに，Kitani などの実㗑 結果であるが，彼らは自己凝縮，再加熱方式で $\mathrm{NaCl}$ の Aerosol を発生させたところ， $\sigma_{g}=0.10 \sim 0.12(\bar{d}=0.45$ $\sim 1.20 \mu$ ) を得て他核插入法との間に差がないことを認 めた。

同様なことは，Homma ${ }^{18)} か ゙$ 图 7 の発生装直を用いて 金属鉛から Aerosol を吐生させた場合に，自己凝鏥法て す HOTS の見られる単分散 Aerosol る生成したことによ って認めた。但し，Carrier gas の流量を多くして，鉛蒸 気がルッボ内を通過する時間が短くなると，発生した鈶 の Aerosol の $\alpha$ は大きくなり, HOTS の見られない多分 散状態となってしまう。

以上の結果から， $\mathrm{NaCl} ＼textrm{P b}$ など，室温より函めて高 い温度で蒸気圷を示すような物筫は，均一な蒸気灣度に した後徐命することによって，他からの核がなくとす自 己凝縮法によって単分散 Aerosol を生成寸ることがわか る。

9）本问克典：学两生工学, J, 19 (昭和 39 年)

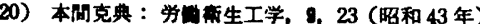

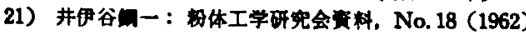

22) Jander, G. and Winkel, A.: Kolloideschr., B3, 5 (1933)

23) Kelly, J. L., Kleinsteuber, A. T., Clinton, S. A. and Dean, $O$. C.: Ind. Ens. Chem. Proc. Des. Dev., 4, 213 (1965)

24) Kerker, M., Matijević, E., Espenscheid, W.F., Farone, W. A and Kitani, S.: J. Colloid Sci., 19, 213 (1964)

25) Kitani, S. and Ouchi, S. : J. Colloid Interface Sci, 23, 200 (1967)

26) 木谷進, 三神尚：化学工学, 25, 206 (1961)

27) Kunkel, W. B.: J. Appl. Phys, 21, 820 (1950)

28) Lane, W. R.: J. Sci. Instrum., 24, 98 (1947)

29) Langer, G. and Lieberman, A. : J. Colloid Sci, 15, 357 (1960)

30) Lauterbach, K. E., Hayes, A. D. and Coelho, M. A.: A.M.A. Arch. Ind. Health., 13, 156 (1956)

31) Lippmann, M. and Albert, R. E. : Amer. Ind. Hyg. Assoc. J., 28, 501 (1967)

32) Lloyd Davies, T. A. : Brit. J. Ind. Med., 3, 111 (1946)

33) Madelaine, G. and Morel, C.: Ann. Oocup. Hyg., 9, 135(1966)

34) Mason, B. J., Jayaratne, O. W. and Wood, J. D. : J. Sci. Inst. rum., 40, 247 (1963)

35) Mason, B. J. and Brownscombe, J. L. : J. Sci. Instrum., 41, 258 (1964)

86) Matijevic, E., Espenscheid, W.F. and Kerker, M. : J. Colloid. Sci., 18, 91 (1963)

37) Matijevic, E., Kitani, S. and Kerker, M. : J. Colloid Sci., 18 229 (1964)

23) Matteson, M. J. and Stöber, W. : J. Colloid_Interface Sci, 23, 203 (1967)

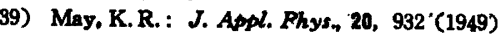


40) May, K. R. : J. Sci. Instrum, 43, 841 (1966)

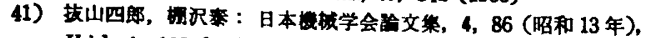
Ibid. 4, 138 (昭和 13 年), Ibid., 5, 131 (昭和 14 年), Ibid。 5,136 (昭和 14 年)

42) Pearson, R. and Langer, G.: Nature, 187, 235 (1960)

43) Perkins, W. A. Leighton, P. A., Grinnell, S. W. and Webster, F.X. Proc. 2nd Nat. Air Pollution Symp. U.S. A. (1952)

44) Preining, O, Sheesley, D. and Djordjevic, N.: J. Colloid Interface Sci., 21, 458 (1967)

45) Princi, F, Church, F. and McGilvray, W.: J. Ind. Hyg. $T a x, 31,106$ (1949)

46) Reist, P.C. and Burgess, W.A.: J. Colloid Interface Sci., 24. 271 (1967)

17) Roker, R. : Staub, 49, 273 (1957)

48) Ryley, D. J.: J. Sci. Instrum, 35, 237 (1958)

49) Ryley. D. J. and Wood, M.R. : J. Sci. Instrum., 40, 303 (1963)

50) Schwendiman, L. C, Postma, A. K. and Coleman, L. F. : Health Phys, 10, 947 (1964)

51) Sihrenk, H. H.: U.S. Bureau of Mines I. C. 7086 (1939)

52) Sonkin, L.S, Lipton, M. A. and Van Hoesen, D. : J. Ind.
Hyg. Tox, 28, 273 (1946)

53) Stead, F.M., Dernehl, C. U. and Nav, C. A. : J. Ind. Hyg. Tox., 26, 90 (1944)

54) Stern, S.: J. Appl. Phys., 3̣0, 952 (1952)

55) Stober, W. and Fink, A.: J. Colloid Interface Sci., 28, 62 (1968)

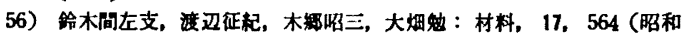
43 年)

57) Swift, D. L.: Ann Occup. Hyg., 10, 337 (1967)

58) Takahashi, K. and Iwai, S.: J. Colloid Interface Sci., 23, 113 (1967)

59) Walkenhorst, W. and Dautrebande, L.: Staub, 24, 505(1964)

60) Walton, W.H. and Prewett, W. C. : Proc. Phys. Soc., B62, 341 (1949)

61) Watson, H.H.: Brit. J. Appl. Phys., 9, 78 (1958)

62) Whitby, K.T., Lundgren, D. A. and Peterson, C. M. : Int. J. Air Wat. Pollu., 9, 263 (1965)

63) Williams, C. E. and Battista, W. P.: J. Ind. Hyg. Tox., 22, 152 (1940)

64) Wright, B.M.: J. Sci. Instrum., 27, 12 (1950)

\section{XXVIII-2. 洷 雺体の粒度分布 則*}

\section{1. ま え かi き}

煙第体は，元来，物質の存在状態としては，不安定 な、いわば過渡的なるのであって，その性状はていどの 差こそあれ，時間的に変化しているすのとみるのか普通 である。このことは，嘢第体粒子の一つ一つについてる そろであるし，系全体についてる同様である。しかし， その変化は全く第秩序に行なわれているわけではなく， それ自身の，あるいはその環境の条件に応した，種々の 物理的, 化学的法則性にるついており，全体的にみて る，その变化の過程には，やはりある種の統計的法則性 が存在し5る。

煙穿体の性質は，形，大きさ，此重，化学組成，浱度 なと，粒子の性状と，温度，压力なと，媒質気体の性状 とによって決まるが, 通常の存在状態において，とくに 微小粒子の場合には, その動力学的性質は, 主として, 粒子の大きさと湌度とによって左右される。すなわち， 粒度分布之粒子数浱度とは，煙等体の物理的性質を表わ す掫も支配的な因子であり，換言すれば，粒度分布にお ける法則性は，㖶霧体粒子の動力学的性筫が集約的传表 現されたるのであるといえる。

- 昭和 43 年 7 月 25 日 学理

** Kanji Takahashi 京䂙大学 工学研究所
高 橋 幹 二**

しかしながら，煙柔体粒子の粒度分布が，その普遍的 法則性という钼点から問題とされてきたのはこく服近の ことであって，その研究成果はまた多くはない。したが って，ここでは，煙葇体以外の分散粒子の粒度分布に関 するかなり古くからの研究成果についても，随時これを 参照しながら，主として敏小煙務体粒子の粒度分布にお。 ける法則性について概説する。

\section{2. 実测例からみた分散粒子の粒度分布}

煙第体粒子の粒度分布については，これまで、気象 学, コロイド学, 化学工学, 衛生工学, 産業医学などの 各分野で問題にされ，粉体粒子の場合と同様に，数多く の測定が行なわれてきた。粒度分布式としても，よく知 られているよ 5 に，対数正規分布や Rosin-Rammler の 式などが広く用いられてきた ${ }^{26) 。 ~}$

各象学の分野では，雨滴の生成核としての煙第体粒子 についてかなり古くからの研究27 31,44,64,67)がある。粒 径測定には，電子顕锺鏡法，荷䉓量测定法，光散乱法な どが用いられてきたが，これらの場合，問題とされる粒 子が $r=10^{-2} \mu \sim 10 \mu$ ていどの微小粒子であって，全粒 子を効果的に湘定するにはかなりの困難があった。しか L, Junge ${ }^{21)}$ は, 数多くの実測にもとつき， $r>0.1 \mu$ の 